\title{
TATA RUANG KANTOR PENUNJANG EFISIENSI KERJA PADA KANTOR TATA USAHA DI SMK NEGERI 1 SALATIGA
}

\author{
Lelahester Rina \\ Progdi Pendidikan Ekonomi \\ FKIP - Universitas Kristen Satya Wacana \\ Entri Sulistari \\ Progdi Pendidikan Ekonomi \\ FKIP - Universitas Kristen Satya Wacana
}

\begin{abstract}
ABSTRAK
Kantor sebagai tempat dan proses dalam melaksanakan kegiatan administrasi suatu organisasi guna mencapai tujuan tertentu. Administrasi sangat penting peranannya karena sebagai pusat informasi yang dibutuhkan oleh pimpinan dalam pengambilan keputusan maupun pihak-pihak yang berkepentingan. Penelitian ini bermuara pada keadaan ruang kantor yang dijadikan sebagai tempat dalam kegiatan administrasi dan semua jenis pekerjaan kantor di sekolah. Hasil penelitian diharapkan memiliki makna dalam manajemen tatanan ruang kerja yang dapat menunjang efisiensi kerja pegawai khususnya staff tata usaha sekolah. Penelitian ini bertujuan untuk mendeskripsikan penataan ruang kantor dalam menunjang efisiensi kerja pada ruang tata usaha SMK Negeri 1 Salatiga. Deskripsi penataan ruang kantor dinilai berdasarkan; (1) Penataan ruangan secara umum, (2) Penempatan staff tata usaha, dan (3) Pengaturan peralatan dan perabot kantor. Hasil penelitian menunjukkan bahwa penataan ruang kantor yang dilaksanakan di SMK Negeri 1 Salatiga tidak menunjang efisiensi kerja. Penataan ruang kantor belum memenuhi tujuan penataan kantor seperti memudahkan gerakan pegawai dari penyimpanan arsip, mobilitas staff dalam melewati lorong utama untuk akses jalan, dan kelancaran proses pekerjaan bersangkutan. Serangkaian pekerjaan dalam prosedur kerja harus melewati berbagai rintangan seperti dokumen, arsip, dan barang-barang yang berserakan dan tidak sesuai dengan tempatnya, jarak yang sempit menghambat proses pekerjaan. Hal ini menjadikan gerakan yang berlebihan karena penataan yang kurang efektif. Selain itu, penataan meja dan kursi kerja staff yang terlalu rapat menghambat jalannya pekerjaan karena membutuhkan waktu dan tenaga dalam berpindah untuk menyelesaikan pekerjaan tertentu. Beberapa kondisi lingkungan fisik kantor seperti kondisi udara, pemerataan cahaya, beberapa perabot memiliki warna yang sudah memudar serta sumber suara yang belum memberikan kenyamanan dan kepuasan staff dalam bekerja. Hasil penelitian tersebut memberikan gambaran bahwa penataan ruang kantor kurang diperhatikan oleh berbagai pihak sekolah karena dianggap sudah baik dalam penataan ruangan kantor. Kesepakatan bersama dalam menjaga dan mempertahankan keindahan ruangan kantor hendaknya menjadi tanggungjawab yang harus dikerjakan dalam menyelesaikan pekerjaan kantor.
\end{abstract}

Kata Kunci: Tata Ruang, Efisiensi Kerja 


\section{PENDAHULUAN}

Administrasi memiliki peranan penting dalam pelaksanaan pendidikan seperti kegiatan dan fungsi manajemen sebagai upaya untuk mencapai tujuan sekolah. Kegiatan administrasif tidak terlepas dari sumber daya manusia yang melaksanakan prosesnya sebagai pengelola informasi. Masing-masing dari pegawai memiliki tugas pokok dan fungsi yang berbeda stau dengan yang lainnya. Oleh karena itu, dalam pelaksanaannya pekerjaan perkantoran tidak dapat dilaksanakan secara individu melainkan berhubungan dengan pekerjaan yang lainnya.

Penyelesaian tugas administratif berorientasi pada pelaksanaan waktu yang cepat dan tepat. Apabila dalam pelaksanaannya mengalami keterlambatan maka akan berdampak dalam kegiatan administrasi sekolah tersebut. Oleh karena itu dalam pelaksanaan kegiatan administrasi sekolah membutuhkan pekerjaan yang efisien dalam penggunaan pikiran, waktu, tenaga maupun biaya yang diperlukan. Lain halnya jika dalam pelaksanaan kegiatan operasional kantor tidak memegang prinsip kemudahan dalam pengerjaannya maka pemborosan akan senantiasa ada. Pemborosan yang terjadi tidak akan menguntungkan pihak sekolah namun akan merugikan baik dari segi pikiran, tenaga, waktu dan biaya yang digunakan.

Tatanan tempat kerja menentukan lancar tidaknya kegiatan kantor, memengaruhi kenyamanan bekerja. Tatanan tempat kerja yang baik akan mendukung penyelesaian pekerjaan kantor. Dengan demikian hal ini akan mencerminkan kualitas dan produktifitas kerja staff tata usaha. Adanya penataan ruangan kantor yang baik akan memudahkan staff tata usaha dalam melaksanakan kegiatan kantor seperti gerakan atau metode kerja maupun alur dalam pelaksanaan prosedur kerja. Manfaat dari pengaturan tata ruang yang baik dapat membuat penyelesaian pekerjaan lebih cepat dan mengurangi kelelahan akibat penataan ruangan kantor yang tidak efisien dan efektif.

Berdasarkan penelitian pendahuluan terhadap kondisi penataan ruang kantor di SMK Negeri 1 Salatiga ditemukan adanya gejala problematis jarak meja antar staff yang satu dengan staff yang lain terlalu sempit sehingga perpindahan alur kerja sulit dilakukan; luas lorong utama untuk berjalan kurang lebar; terdapat banyak kertas, bukubuku dan tumpukan kardus yang berserakan di sekitar ruangan; banyak almari yang diletakkan di dekat pintu menimbulkan ruangan gelap. Oleh karena itu, dilakukan upaya dalam memecahkan permasalahan tersebut melalui penelitian tentang penataan ruang kantor tata usaha.

Adapun penelitian ini bertujuan untuk mendeskripsikan penataan ruang kantor dalam menunjang efisiensi kerja pada kantor tata usaha di SMK Negeri 1 Salatiga. Hasil penelitian diharapkan dapat dijadikan bahan pertimbangan dalam menentukan kebijakan sekolah dalam penataan ruangan kaitannya dengan efisiensi kerja yang didapatkan. Pencapaian tujuan penelitian dilakukan dengan menjadikan objek penelitian di SMK Negeri 1 Salatiga melalui subjek penelitian yaitu penataan ruang kantor tata usaha di SMK Negeri 1 Salatiga.

\section{TINJAUAN PUSTAKA}

\section{Kantor}

Menurut Moekijat (2002:17), kantor 
itu sebagai tempat dimana pekerjaan tata usaha dilakukan. Nurasih dan Rahayu (2014:3) juga mengemukakan, kantor merupakan suatu istilah yang berasal dari bahasa Belanda, kantoor adalah bagian dari organisasi yang menjadi pusat kegiatan administrasi dan tempat pengendalian kegiatan informasi. Sejalan dengan pendapat Nurasih Nuraida (2014:1), kantor adalah tempat diselenggarakannya kegiatan tata usaha yang di dalamnya terdapat ketergantungan sistem antara orang, teknologi, dan prosedur kerja untuk menangani data dan informasi mulai dari menerima, mengumpulkan, mengolah, menyimpan sampai menyalurkannya kepada pihak-pihak yang berkepentingan.

\section{Tata Ruang Kantor}

Menurut Quible dalam Sukoco (2007: 189), tata ruang kantor adalah penggunaan ruang secara efektif serta mampu memberikan kepuasan kepada pegawai terhadap pekerjaan yang dilakukan, maupun memberikan kesan yang mendalam bagi pegawai. Sedangkan Terry (dalam Gie, 2000:186) berpendapat tata ruang kantor adalah penentuan mengenai kebutuhankebutuhan ruang dan tentang penggunaan secara terperinci dari ruang ini untuk menyiapkan suatu susunan yang praktis dari faktor-faktor fisik yang dianggap perlu bagi pelaksanaan kerja perkantoran dengan biaya yang layak.

Tujuan tata ruang kantor adalah memperlancar pekerjaan kantor sehingga menjadi lebih efektif, menggunakan seluruh ruangan yang ada dengan optimal, menciptakan kondisi kerja yang baik, memudahkan pengawasan terhadap pekerjaan kantor (meningkatkan estetika), memberikan fleksibilitas yang tinggi, menjaga keseim- bangan antara alat dan staff (Maryati, 2008: 148). Ada beberapa manfaat yang dapat diperoleh dari adanya penataan ruang kantor menurut Gie (2000:188) antara lain: mencegah penghamburan tenaga dan waktu para pegawai karena berjalan modar-mandir yang sebetulnya tidak perlu, menjamin kelancaran proses pekerjaan yang bersangkutan, memungkinkan pemakaian ruang kerja secara efisien, mencegah para pegawai di bagian lain terganggu oleh publik yang akan menemui suatu bagian tertentu.

Tata ruang kantor selain berkaitan tentang bagaimana penataan ruang itu sendiri juga berkaitan dengan lingkungan fisik yang ada pada ruangan tersebut. Nuraida (2014:174-179) membagi lingkungan fisik kantor menjadi empat yaitu (1) Cahaya merupakan faktor penting untuk meningkatkan efisiensi kerja pegawai karena memengaruhi kesehatan dan keselamatan serta kelancaran kerja, (2) Warna mempunyai pengaruh penting terhadap penerangan kantor, (3) Udara dalam hal ini lebih dilihat dari sisi suhu/temperatur, kelembapan, sirkulasi/ventilasi dan kebersihan, (4) Bunyi/ suara terutama untuk pekerjaan yang membutuhkan konsentrasi, faktor suara dapat memengaruhi efisiensi pekerja karena suara yang bising dapat mengganggu dan dapat berpengaruh pada kesehatan pekerja, (5) Musik dapat memengaruhi keadaan fisik dan mental pegawai.

\section{Pengaturan Peralatan dan Perabot Kantor}

Menurut Ensiklopedi Administrasi dalam Nurasih dan Rahayu (2014:53) perlengkapan atau peralatan kantor adalah segenap benda yang dipergunakan untuk membantu kelancaran tugas-tugas tata usaha atau adminitrasi, yang terdiri perabot kantor, 
mesin kantor, bekal kantor dan hiasan kantor. Perabot kantor terdiri atas lemari, lemari arsip, lemari katalog, lemari besi, meja, kursi, rak. Asbak dan perlengkapan lainnya yang diberikan kepada kerani-kerani perseorangan atau untuk umum. Peralatan dan benda-benda yang sudah terbagi tersebut sangatlah membantu dalam bekerja bagi seorang staff. Oleh karena itu dalam penataan ruang kantor benda ini juga dalam penempatannya akan mempengaruhi cara kerja pegawai tata usaha.

\section{Efisiensi Kerja}

Menurut Gie (2014:53), efisiensi adalah suatu asas-asas dasar tentang perbandingan terbaik antara suatu usaha dengan hasilnya. Sedangkan menurut Umam (2014: 169) mendefinisikan pengertian efisiensi adalah suatu asas dasar tentang perbandingan terbaik antara suatu usaha dengan hasilnya, atau dari berbagai alternatif usaha kerja yang dapat kita lakukan mendapatkan hasil yang maksimum dengan pengorbanan yang minimal. Berdasarkan pengertian tersebut maka sumber-sumber yang dapat diefisiensikan kerja adalah pikiran, tenaga, waktu, ruang, benda-benda termasuk uang.

\section{METODE}

Penelitian ini merupakan penelitian deskriptif kuantitatif, dimaksudkan untuk mendeskripsikan penataan ruang kantor tata usaha dalam menunjang efisiensi kerja pada kantor tata usaha di SMK Negeri 1 Salatiga. Objek penelitiannya adalah kantor tata usaha SMK Negeri 1 Salatiga. Sedangkan unit analisis dan unit observasi adalah penataan ruang kantor tata usaha SMK Negeri 1 Salatiga melalui observasi dan wawancara yang dilakukan kepada staff tata usaha, koordinator tata usaha dan kepala
SMK Negeri 1 Salatiga. Penataan dibagi menjadi beberapa indikator yang akan diteliti yaitu penataan ruangan secara umum, penempatan staff tata usaha di dalam ruangan, dan pengaturan peralatan dan perabot kantor.

\section{HASIL PENELITIAN DAN PEMBAHASAN}

\section{Penataan ruang kantor}

Ruang tata usaha di SMK Negeri 1 Salatiga terdiri dari staff baik bagian paling depan yang melayani publik hingga koordinator tata usaha yang berada di belakang ruang tata usaha, peralatan dan perabot yang digunakan dijadikan dalam satu ruangan. Jenis ruang tata usaha SMK N 1 Salatiga ini adalah terbuka, hal ini sesuai dengan teori Standingford bahwa kantor terbuka yaitu kantor dimana juru tulis, penyelia dan kadang manajer ditampung di dalam satu wilayah yang luas.

Beberapa kondisi lain di tata usaha SMK Negeri 1 Salatiga antara lain barangbarang atau dokumen-dokumen baik yang masih digunakan maupun yang tidak digunakan diletakkan di lantai, meja, kursi, di atas almari, dan sekitar ruangan tata usaha. Hal ini menyebabkan akses untuk jalan staff terasa sulit karena terhalang oleh barang-barang dan dokumen yang berserakan. Staff akan menggeser dokumen, barang yang merintangi ketika mereka melintas di jalan ruang tata usaha. Kondisi ini menyebabkan staff tata usaha terhambat dalam menyelesaikan pekerjaan karena harus menggeser terlebih dahulu. Hal ini tidak sesuai dengan teori yang diungkapkan oleh Nuraida tujuan dalam penataan ruang kantor adalah...memudahkan setiap gerakan para pegawai dari tempat penyimpanan arsip, 
memberikan rasa aman dan keleluasaan pribadi.

Sebuah ruangan yang berisi data pokok pendidikan (dapodik) berada dalam satu ruangan tata usaha. Ruangan ini tidak efektif bila diletakkan di dalam ruang tata usaha karena selain bersifat rahasia, ruang dapodik ini cukup memakan tempat ruang tata usaha. Bukan hanya letak yang kurang tepat, pengalihan fungsi terjadi dalam ruang dapodik ini karena ruangan tersebut dijadikan tempat penyimpanan barang lain seperti tumpukan kertas yang berantakan, beberapa kardus kosong, peralatan upacara yaitu stand microphone, tinta printer, owdner yang berserakan, dan barang-barang lainnya.

\section{Penempatan staff tata usaha}

Penempatan pegawai staff tata usaha di SMK Negeri 1 Salatiga diurutkan berdasarkan tugas pokok dan fungsi dari masing-masing pegawai dengan menghadap arah yang sama. Jarak meja antar staff hampir tidak ada jarak. Penataan meja kerja yang demikian akan menghambat staff jika hendak beranjak dari meja kerjanya menuju tempat lain dalam menyelesaikan pekerjaannya. Hal ini disebabkan staff harus menggeser kursi staff lain atau meminta izin dan menunggu staff lain beranjak atau harus berputar mencari jalan untuk keluar juga dalam setiap jalan terdapat rintangan kursi, berkasberkas, buku, arsip dan barang-barang lainnya sehingga mereka harus menghindari barang-barang tersebut atau menggesernya. Lorong utama untuk jalan staff juga sempit sehingga terkadang bergantian ketika berpapasan dengan staff lain.

Hal tersebut tidak sesuai dengan teori Gie yang menyatakan bahwa teknik yang dapat digunakan adalah ... diantara baris-baris meja itu disediakan lorong untuk keperluan lalu lintas para pegawai sebaiknya di bagian tengah terdapat sebuah lorong utama yang lebarnya $120 \mathrm{~cm}$, lorong-lorong lainnya cukup selebar $80 \mathrm{~cm}$. Lebar $120 \mathrm{~cm}$ itu dibuat berdasarkan perhitungan bahwa lebar badan seseorang yang normal kira-kira $60 \mathrm{~cm}$ sehingga lorong tersebut dapat dijalani dua orang dengan tanpa bersing-gungan waktu berpapasan oleh 2 orang. Sedangkan teknik lainnya adalah jarak antara sesuatu meja dengan meja yang dimuka atau dibelakangnya (ruang untuk duduk pegawai) selebar $80 \mathrm{~cm}$. Hal ini diperkuat dengan prinsip tata ruang yang diungkapkan oleh Nurasih dan Rahayu adalah usahakan untuk menjadikan tata ruang yang bisa membuat aliran pekerjaan menjadi sederhana, ruang lantai harus terbebas dari semua rintangan, setiap perlengkapan kerja harus berada dekat dengan penggunanya, jumlah jalan atau koridor yang memadai pada setiap ruangnya dan luasnya harus memadai.

\section{Pengaturan peralatan dan perabot kantor}

Penataan peralatan dan perlengkapan kantor di ruang tata usaha SMK Negeri 1 Salatiga sebagian sudah memperhatikan kedekatan letak peralatan yang sering digunakan oleh masing-masing pegawai. Kedekatan peralatan yang sering digunakan seperti meja dan laci memudahkan staff dalam menjangkau peralatan/ perabot yang sering digunakan dan mempertimbangkan efisiensi tenaga dan waktu yang digunakan. Hal ini sudah sesuai dengan teori Gie prinsip menyusun ruang kantor adalah...lemari dan alat-alat perlengkapan lainnya taruh didekat pagawai-pegawai yang paling sering mempergunakan benda-benda itu. Disisi lain, penjangkauan beberapa peralatan atau perabot lain oleh beberapa staff dirasa cukup jauh karena harus berpindah tempat dari 
tempat duduknya dengan melewati rintangan yang ada pada lorong. Hal akan memerlukan waktu yang lebih lama karena harus berputar dari meja ke meja untuk bisa keluar.

Penggabungan penyimpanan arsip kesiswaan dengan arsip kepegawaian yang ada di filling cabinet dua pintu yang berada di bagian depan ruang tata usaha sebagai bukti terbatasnya peralatan atau perabot yang digunakan. Beberapa almari/perabot yang lainnya sudah cukup rapuh dan tua. Penumpukan almari dikarenakan perabotperabot tersebut berasal dari bantuan pemerintah dan tidak ada tempat untuk menyimpan sehingga masih tetap digunakan. Selain itu, almari arsip pada bagian kesiswaan masih dirasa kurang karena beberapa dokumen kesiswaaan dan kepegawaian diletakkan di luar almari seperti di atas meja, atas almari, lantai dan beberapa tempat kosong lainnya. Keadaan yang yang kurang tertata ini menyebabkan ruangan terasa sesak karena berbagai dokumen dan barang-barang diletakkan diberbagai tempat seperti di sekitar lantai, diatas meja yang kosong, di atas almari bahkan di atas kursi.

\section{Efisiensi kerja}

Penataan ruang kantor tidak terlepas dari adanya lingkungan fisik yang berada disekitar tempat ruang kerja. Lingkungan fisik di SMK Negeri 1 Salatiga dapat dikelompokkan menjadi beberapa bagian yaitu dari udara, cahaya, warna pada dinding dan peralatan, dan suara yang ditimbulkan di sekitar ruang tata usaha.

a. SMK Negeri 1 Salatiga masih menggunakan udara alami tanpa ada alat pengontrol udara. Akses dua pintu dan ventilasi yang dibuka pada jam kerja mengakibatkan angin masuk cukup besar dan membawa banyak debu dan kotoran ke dalam ruangan. Kondisi yang kotor akan menjadi sebab penyakit. Hal ini tidak sesuai dengan teori Nuraida bahwa Air Conditioner (AC) mengatur keadaan udara dengan mengawasi suhu, peredaran, kelembapan, dan kebersihan. Efisiensi pegawai kantor menunjukkan kenaikan rata-rata 20 persen setelah diberi AC.

b. Kondisi yang sebenarnya di SMK Negeri 1 Salatiga sudah cukup memberikan penerangan cahaya melalui beberapa lampu dan memanfaatkan sinar matahari. Cahaya yang diberikan berasal dari lampu yang berada pada langit-langit sebagai sumber pencahayaan ruang tata usaha. Namun cahaya belum merata semuanya karena terhalang oleh beberapa peralatan dan perabot kantor yang tinggi dan tidak beraturan seperti almari arsip.

c. Pemakaian warna perabot yang ada di SMK Negeri 1 Salatiga klasik dan tidak terlalu mencolok. Hal ini karena sebagian besar penggunaan perabot berasal dari kayu. Sedangkan warna dinding ialah warna crem sama dengan warna pada ruangan lainnya di lingkup sekolah. Namun penggunaan warna pada dinding sudah mulai memudar bahkan adanya kotoran yang menempel pada dinding ruangan membuat ruangan menjadi kurang bersih. Selain itu, beberapa peralatan dan perabot kantor yang sudah lama dan masih disimpan juga rapuh karena binatang kecil yang merusakkan.

d. Keadaan suara SMK Negeri 1 Salatiga berasal dari karyawan, tamu, guru dan siswa. Selain itu berasal dari lingkungan sekitar seperti jalan raya. Kebisingan dari luar ruangan terjadi pada waktu-waktu tertentu saja. Suara yang cukup mengganggu ialah dari karyawan sendiri yang berinteraksi dan berdiskusi antar 
karyawan bahkan guru. Hal ini tidak sesuai dengan teori Nuraida terutama untuk pekerjaan yang membutuhkan konsentrasi, faktor suara dapat memengaruhi efisiensi pekerja karena suara yang bising dapat mengganggu dan dapat berpengaruh pada kesehatan. Selain itu, penggunaan akses pintu staff digunakan oleh semua orang sehingga hal ini mengurangi konsentrasi staff yang sedang bekerja dalam ruangan.

e. Efisiensi kerja

\section{- Waktu}

Dampak yang diakibatkan dari segi waktu yang dihabiskan ialah menghambat dalam proses penyelesaian pekerjaan. Hal ini ditandai dengan lamanya proses pencarian kembali arsip yang dapat menyebabkan keterlambatan proses surat-menyurat karena cukup luasnya ruangan, tenaga yang dihabiskan bolak-balik karena terbatasnya peralatan seperti printer atau mesin fotokopi. Jarak yang sempit mengakibatkan jarak tempuh yang lebih panjang karena harus minta izin untuk lewat lorong yang bersentuhan dengan tempat duduk staff lain bahkan harus berputar untuk keluar dari tempat duduk.

- Biaya

Efisiensi biaya yang dapat dilakukan pada staff tata usaha SMK Negeri 1 Salatiga dapat dilihat dari penempatan staff tata usaha dalam satu ruangan. Pengaturan ruang terbuka akan menurunkan penggandaan informasi yang ada, komunikasi menjadi satu kesatuan dan tersentral antar unit yang lainnya. Namun, apabila staff tidak dapat menyelesaikan tepat waktu maka biaya akan dikeluarkan lebih banyak karena staff harus lembur dan memerlukan biaya listrik yang lebih banyak.
- Tenaga

Keadaan ruang yang cukup luas mengakibatkan staff tata usaha harus membutuhkan tenaga lebih banyak dalam melaksanakan pekerjaannya. Beberapa kendala dalam tenaga yang dihabiskan adalah staff yang berusaha keluar dari tempat duduknya untuk menyelesaikan pekerjaan tertentu sehingga harus menarik kursinya, meminta izin atau menunggu staff lainnya berpindah karena jarak kursi dengan meja terlalu rapat. Penggunaan tenaga yang cukup banyak ialah penjangkauan dalam mencari arsip yang ada didalam almari yang cukup jauh dari tempat duduk sehingga harus melewati rintangan dalam berjalan. Seringkali dalam mencari arsip yang diperlukan staff tidak langsung mendapatkan melainkan harus mencari di almari lainnya. Berbagai aktivitas tersebut akan menghabiskan tenaga lebih banyak.

- Hasil

Hasil pekerjaan dapat dikerjakan dengan baik meskipun terkadang mengalami sedikit keterlambatan dan penumpukan pekerjaan pada waktu tertentu saja. Hal ini disebabkan karena penumpukan tugas dari pemerintah pada waktu-waktu tertentu. Seringkali terjadi antrian dalam melayani pihak-pihak tertentu karena banyaknya tugas pekerjaan harus segera diselesaikan. Bahkan terjadi kendala seperti antrian peralatan seperti printer sehingga menunggu staff lainnya dalam menggunakan printer. Pekerjaan yang kurang terorganisir ini akan menghambat dalam penyelesaian 
tepat waktu sehingga lembur kerja sebagai solusinya.

Penataan memberi dampak yang berarti dalam efisiensi baik waktu, tenaga, biaya dan hasil yang dicapai dalam mencapai tujuan sekolah. Oleh karena itu perlu memperhatikan peralatan atau perabot yang digunakan yang mengakibatkan ruangan terasa sesak dan sempit, kondisi peralatan yang ada sehingga dapat diperbaiki maupun diganti serta ditambahkan.

\section{KESIMPULAN}

Berdasarkan tujuan penelitian dan temuan penelitian, maka diperoleh kesimpulan deskripsi penataan ruang kantor dalam menunjang efisiensi kerja staff tata usaha di SMK Negeri 1 Salatiga sebagai berikut:

Penataan ruang kantor yang dilaksanakan di SMK Negeri 1 Salatiga tidak menunjang efisiensi kerja. Penataan ruang kantor belum memenuhi tujuan penataan kantor seperti memudahkan gerakan pegawai dari penyimpanan arsip, mobilitas staff dalam melewati lorong utama untuk akses jalan, dan kelancaran proses pekerjaan bersangkutan. Serangkaian pekerjaan dalam prosedur kerja harus melewati berbagai rintangan seperti dokumen, arsip, dan barang-barang yang berserakan dan tidak sesuai dengan tempatnya, jarak yang sempit menghambat proses pekerjaan. Hal ini menjadikan gerakan yang berlebihan karena penataan yang kurang efektif.

Selain itu, penataan meja dan kursi kerja staff yang terlalu rapat menghambat jalannya pekerjaan karena membutuhkan waktu dan tenaga dalam berpindah untuk menyelesaikan pekerjaan tertentu. Hal tersebut akan membutuhkan waktu lebih lama, jarak tempuh menjadi semakin panjang, dan menyebabkan kelelahan dimana staff masih mengerjakan pekerjaan yang lainnya.

Beberapa kondisi lingkungan fisik kantor seperti kondisi udara yang masih alami menjadikan pegawai memanfaatkan ruangan untuk merokok, penambahan peralatan akan sangat dibutuhkan kaitannya dengan udara yang dapat dikontrol. Pemerataan cahaya dalam ruangan kantor akan sangat memengaruhi proses pekerjaan sehingga penataan perabot yang menghalangi cahaya dapat diperhatikan. Beberapa perabot memiliki warna yang sudah memudar seperti almari, meja, kursi dan lain sebagainya. Selain itu, sumber suara yang dihasilkan karyawan sendiri mengganggu konsentrasi dan menunda pekerjaan. Dari berbagai kondisi lingkungan fisik, tata ruang akan menentukan rasa aman dan puas dalam bekerja yang mana akan berpengaruh pada efisiensi kerja karena hal ini saling berhubungan. Secara keseluruhan dampak penataan yang tidak sesuai menjadikan proses pekerjaan menjadi semakin lama, tenaga yang dibutuhkan semakin besar, keterlambatan penyelesaian pekerjaan akan menambah biaya, dan hasil yang diberikan belum memberikan yang sebaik-baiknya karena terhambat oleh beberapa penataan yang tidak efektif.

\section{SARAN}

\section{Staff Tata Usaha}

Hendaknya rutin mengikuti kegiatan jumat bersih dalam memelihara baik peralatan/perabotan, menyimpan dokumen arsip pada tempat penyimpanan dan memperhatikan lingkungan fisik disekitarnya agar ruangan terasa rapi, indah dan nyaman setiap harinya dan fokus pada pekerjaan yang harus segera diselesaikan dengan 
mengurangi diskusi dengan staff lainnya maupun guru-guru yang singgah di ruang TU pada jam kerja.

\section{Koordinator Tata Usaha}

Hendaknya memperhatikan lingkungan fisik yang mengganggu seperti udara, cahaya, suara, dan pewarnaan pada dinding dan peralatan serta kelengkapan peralatan yang digunakan; merencanakan penambahan perabot/peralatan seperti printer, AC, mesin foto kopi, tenaga kerja penerima telepon tata usaha, meja dan kursi tamu staf tata usaha, almari arsip dan sekat antar meja staff dalam meningkatkan efisiensi kerja staff tata usaha.

\section{Kepala SMK Negeri 1 Salatiga}

Hendaknya memberikan pengawasan terhadap kinerja staff tata usaha melalui CCTV di ruang tata usaha maupun kunjungan langsung di ruang tata usaha pada waktu tertentu; mendukung penambahan peralatan, perlengkapan dan perabot-perabot berkualitas yang dibutuhkan oleh staff tata usaha demi menunjang efisiensi kerja; dan mendukung perubahan tatanan ruang TU yang dapat menunjang efisiensi kerja staff tata usaha.

\section{Peneliti Selanjutnya}

Bagi peneliti selanjutnya yang ingin melakukan penelitian tentang penataan ruang kantor penunjang efisiensi kerja memahami wawasan mengenai penataan ruang kantor beserta komponen-komponen yang ada dalam tata ruang.

\section{DAFTAR PUSTAKA}

Gie, T. L. 2000. Administrasi Perkantoran Modern. Yogyakarta: Liberty.

Mills, Geoffrey, Oliver Standingford dan Robert C. Appleby. 1991. Manajemen Perkantoran Modern Edisi ketujuh dari Office Organization and Methods. Tangerang: Bina Rupa Aksara .

Moekijat. 2002. Tata Laksana Kantor Manajemen Perkantoran. Bandung: Mandar Maju.

Nuraida, I. 2014. Manajemen Administrasi Perkantoran. Yogyakarta: Kanisius.

Nurasih, Lina dan Sri Rahayu. 2014. Manajemen Sekretaris Itu Gampang. Jakarta: Dunia Cerdas.

Sayuti, A. J. 2013. Manajemen Kantor Praktis. Bandung: Alfabeta.

Umam, K. 2014. Manajemen Perkantoran Referensi untuk Para Akademis dan Praktisi. Bandung: Pustaka Setia. 